\title{
O papel hermenêutico do conceito de totalidade em Theodor W. Adorno
}

\author{
The hermeneutic role of the concept of totality in Theodor W. \\ Adorno
}

Gabriel Petrechen Kugnharski

gabrielkugnharski@hotmail.com

(Universidade de São Paulo, São Paulo, Brasil)

\begin{abstract}
Resumo: O artigo apresenta uma interpretação da função que o conceito de totalidade assume no modelo de dialética desenvolvido por Theodor W. Adorno na década de 1960, sobretudo na obra Dialética Negativa, de 1966. Além dessa obra, outros textos do mesmo período também são examinados, tais como Três estudos sobre Hegel e Capitalismo tardio ou sociedade industrial. Realiza-se também um levantamento das principais posições da literatura acerca dessa questão. 0 objetivo é sustentar que, embora crítico da totalidade, Adorno retém esse conceito com o intuito de se contrapor às correntes filosóficas dominantes em sua época, sobretudo o positivismo lógico.
\end{abstract}

Palavras-chave: Theodor Adorno; teoria crítica; totalidade; dialética negativa.

\begin{abstract}
The article presents an interpretation about the function of the concept of totality in the model of dialectics developed by Theodor W. Adorno in the 1960s, especially in the Negative Dialectics, 1966. In addition to this work, other texts from the same period are also examined, such as Hegel: Three Studies and Late Capitalism or Industrial Society. It also undertakes a survey of the main positions of the literature on this issue. The aim is to claim that, although critical of the concept of totality, Adorno retains this concept in order to counteract the dominant philosophical currents of his time, especially logical positivism.
\end{abstract}

Keywords: Theodor Adorno; critical theory; totality; negative dialectics.

DOI: http://dx.doi.org/10.11606/issn.2318-9800.v24i1p67-81

Nas palavras de Marc Sommer (2016, p.64), o conceito de totalidade não é apenas um dos principais conceitos da Dialética Negativa, mas também um dos mais problemáticos. Outros autores, como Fredric Jameson (1997) e Herbert Schnädelbach (1983), também ressaltam a centralidade desse conceito no pensamento de Adorno. Embora grande parte da literatura reconheça que a totalidade possui um papel significativo em várias esferas do pensamento do filósofo frankfurtiano, não há consenso sobre o papel que essa categoria desempenha em sua concepção de dialética.

Um dos objetos de disputa dessas leituras é a própria posição da dialética negativa em relação à dialética hegeliana. Em dedicatória a Horkheimer presente 
em Minima Moralia (1951), Adorno afirma que o método ali desenvolvido busca ensinamento em Hegel, mas que não obstante mantém-se crítico em relação ao tratamento dado pelo filósofo idealista à categoria do indivíduo, na medida em que "a concepção de uma totalidade harmônica na travessia dos seus antagonismos" teria levado Hegel a "atribuir dignidade inferior à individuação na construção do todo" (Adorno, 2008, p.11). Assim, o apoio que o método em Minima Moralia afirma encontrar em Hegel é simultâneo a um afastamento progressivo em relação a algumas concepções centrais da dialética hegeliana, como a categoria da totalidade, e o mesmo parece valer para a Dialética Negativa e outras produções da década de 1960. Em outro momento da obra de 1951, Adorno (idem, p.46) proclamará a conhecida sentença segundo a qual "o todo é o não verdadeiro" [Das Ganze ist das Unwahre], invertendo o dito hegeliano "o verdadeiro é o todo" [Das Wahre ist das Ganze] presente na Fenomenologia do espírito.

Por um lado, Adorno toma para si conceitos da dialética hegeliana tais como - além de totalidade - também mediação, síntese, espírito, imanência, negação determinada, entre outros. Por outro lado, esses conceitos são tomados à luz da recepção adorniana de Nietzsche e Marx (cf. Rose, 1978, p.55), e são, portanto, deslocados de sua concepção original e acrescidos de novas colorações. Mesmo um autor como Jay Bernstein (2004, p.20), que busca enfatizar os elementos hegelianos contidos nas análises de Adorno, afirma que sua filosofia seria "a articulação do que é ser hegeliano depois de Hegel, depois de Marx, depois de Nietzsche e acima de tudo depois de dois séculos de história brutal em que o momento de realização da filosofia, a esperança dos hegelianos de esquerda tal como Marx, foi perdido"'. Ainda assim, não é infrutífera a questão sobre se a categoria da totalidade, diante da qual Adorno se posiciona de maneira tão crítica, não retornaria subterraneamente como sustentáculo de suas análises no âmbito da crítica social, e mesmo de sua concepção própria de dialética.

Se o todo não é o verdadeiro, como o queria Hegel, esta categoria ainda parece guardar um conteúdo de verdade que as análises adornianas buscam simultaneamente extrair e criticar. Como pretendemos mostrar, Adorno desloca a categoria da totalidade de sua posição ocupada na dialética hegeliana, mas não a suprime. Ao contrário, ele concede a ela um papel importante em diversos âmbitos de suas reflexões. Por mais que na maioria das vezes ela apareça em contextos essencialmente críticos, como uma "má totalidade", e assim completamente invertida em relação ao lugar que ocupa na dialética hegeliana, é difícil negar que ela mantém ainda seu potencial crítico intacto (cf. Repa, 2011, p.274). O próprio diagnóstico em torno da concepção de Mundo administrado [Verwaltete Welt] seria uma das expressões totalizantes que

1 A tradução para o português desse e outros comentários originalmente em língua inglesa ou alemã são de nossa responsabilidade. 
o filósofo frankfurtiano frequentemente emprega em seus textos.

Pretende-se, portanto, desdobrar os principais aspectos desse debate, e com isso jogar luz sobre o devido lugar que a totalidade ocupa na dialética negativa, mostrando que Adorno concede a essa categoria uma função hermenêutica essencial para a crítica do conhecimento e da sociedade.

\section{A ênfase na micrologia}

Como afirmamos anteriormente, não são poucos os autores que apontam para a centralidade da categoria da totalidade na dialética negativa de Adorno. Para Jameson (1997, p.46), "ao insistir frequentemente em denunciar sistemas (sejam eles lógicos, filosóficos ou políticos)" e ao "propor uma dialética radicalmente assistemática, Adorno retém o conceito totalizante de sistema e o torna inclusive o centro de seu próprio pensamento". Em um sentido semelhante, Schnädelbach (1983, p.89) aponta que a totalidade continua tendo um lugar central no pensamento de Adorno, como possuía também em Hegel. O aspecto fortemente totalizante da teoria de Adorno, que o teria levado a uma espécie de "holismo", fez com que o filósofo frankfurtiano permanecesse, a despeito de toda a crítica a Hegel, próximo a este. Segundo Schnädelbach (1983, p.90), até mesmo o não idêntico é um conceito totalizante. Por mais que Adorno sempre trate do todo como o “não verdadeiro", ele está sempre presumido, mesmo lá onde se trata de uma análise do particular.

De fato, mesmo em suas análises micrológicas, Adorno busca mostrar como o particular está marcado pelo universal. Isso porque "o motivo negativo da filosofia da identidade conservou sua força; nada particular é verdadeiro, nenhum ente é ele mesmo tal como a sua particularidade o reivindica" (Adorno, 2009, p.132). Para Schnädelbach (1983, p.90) a tese de que a dialética deve apresentar o particular como marcado pelo todo, ao passo que o todo mesmo não pode ser racionalmente explicado, pois sua própria racionalidade contamina qualquer explicação coerente, leva Adorno a uma "ontologia holística, que não pode ser justificada de maneira idealista, nem confirmada de maneira empírica”. Tal leitura não nos parece, porém, inteiramente acertada, e abordaremos mais adiante algumas passagens do texto de Adorno que apontam suas limitações.

A Dialética Negativa parte de uma crítica da dialética em sua versão idealista, sobretudo em relação ao papel da identidade. Cabe lembrar que, no prefácio da obra, Adorno coloca para si o esforço de "romper, com a força do sujeito, o engodo de uma subjetividade constitutiva” (Adorno, 2009, p.8). Nesse ponto, Adorno se distancia de Hegel, pois, na dialética idealista, a verdade é a verdade do todo: se esta "não fosse previamente pensada, os passos dialéticos perderiam sua motivação e direção" 
(idem, p.17). Na longa introdução, nas duas primeiras partes e nos três modelos finais que compõem a obra, Adorno desdobra o intento paradoxal do prefácio, expressando em inúmeras passagens, em direção contrária à dialética hegeliana, que a dialética não é o todo. ${ }^{2}$ Isso porque a totalidade corresponde a um estado de dominação, de supressão do não-idêntico, e a dialética negativa deve, portanto, "se opor à totalidade, imputando-lhe a não-identidade consigo mesma que ela recusa segundo seu próprio conceito" (idem, p.128).

Segundo Sommer (2016, p.65), por mais que Adorno claramente articule uma diferença em relação a Hegel no uso normativo da totalidade, seu pensamento permanece dependente de tal conceito, mesmo que sob outra configuração. Adorno ainda insistiria na categoria da totalidade como "um meio para mostrar a imediatidade ilusória do individual e para convencer de sua mediação através do todo" (idem, ibidem). Sommer considera insuficiente a explicação de Jay, a saber, de que a influência do contexto intelectual no qual Adorno se inseria (em meio a nomes tais como Hans Cornelius, Siegfried Kracauer, Walter Benjamin e Arnold Schönberg) teria fornecido a principal motivação para que Adorno articulasse em sua filosofia uma espécie de corretivo para o conceito hegeliano-marxista de totalidade. De fato, tal contexto pode ser uma parte da explicação, e tanto Jay (1984) quanto BuckMorss (1977) oferecem uma análise pormenorizada das influências que mantiveram o jovem Adorno longe da filosofia de Hegel e mais próximo de um olhar micrológico sobre a realidade, olhar este que permanece em toda trajetória intelectual do filósofo. No entanto, essa explicação carece de complemento, pois Adorno não deixa de ressaltar, em vários momentos, que a reflexão sobre a micrologia sem referência à totalidade não é possível, e, portanto, essa categoria segue sendo fundamental em seu pensamento.

Em suas análises micrológicas, Adorno busca mostrar como o particular é em grande medida determinado pelo universal. Talvez um dos melhores exemplos disso possa ser encontrado no "método" empregado em Minima Moralia, onde tudo - do trato com portas, ato de dar presentes, relação com refrigeradores ou carros, até gentileza e hospitalidade - atesta o modo pelo qual o universal se manifesta no particular (Jaeggi, 2005, p.65). Para Adorno, a verdade não reside nem no polo do individual, nem no polo do universal. Com efeito, a separação abstrata entre eles deve ser criticada. Ambos devem ser considerados em vista de sua não-identidade. 0 todo, porém, não é imediatamente cognoscível. Ele não é nenhum “dado”, mas possui

2 Podemos citar uma passagem da Dialética Negativa que confirma esse ponto: "Sem a tese da identidade, a dialética não é o todo; mas então também não é nenhum pecado capital para ela abandonar essa tese em um passo dialético. Reside na determinação de uma dialética negativa que ela não se aquiete em si, como ela fosse total; essa é a sua forma de esperança" (Adorno, 2009 , p.336). Em seus seminários de Introdução à dialética, ministrados em 1958, Adorno fala em uma "dialética aberta", que será defendida por ele, por contraposição à "dialética fechada", que corresponderia à dialética idealista de Hegel (Adorno, 2015a, p.36). 
uma função hermenêutica: ele é o centro de força que afeta os fatos, a essência que se manifesta em cada particular (Sommer, 2016, p.77). Cabe à filosofia abandonar a pretensão de um conhecimento do todo e voltar seu olhar "para o âmbito em relação ao qual Hegel, em sintonia com a tradição, expressou o seu desinteresse: o âmbito do não-conceitual, do individual e particular" (Adorno, 2009, p.15). Ao concentrar seu olhar no particular, e somente nele, a dialética descobre os traços fundamentais da totalidade à qual o particular aparece aprisionado.

\section{Crítica do positivismo}

Mesmo mantendo-se crítico em relação ao conceito de totalidade, é também a ele que o filósofo frankfurtiano recorre na introdução ao texto conhecido como "Controvérsia sobre o positivismo na sociologia alemã", que resultou da participação de Adorno em um congresso ocorrido em 1961. O debate se deu entre duas correntes da sociologia da época: a dialética e a sociologia positivista. De um lado, estava Adorno como defensor da dialética, e do outro, Karl Popper, considerado por Adorno como "positivista”, embora o próprio Popper negasse tal denominação.

Enquanto a "sociologia dominante", nas palavras de Adorno, "reconhece somente a vigência de fenômenos", a dialética, ao se ater à mediação entre o fenômeno e a totalidade, expressa que "os fatos não são aquilo tido por último e impenetrável”, mas que "neles se manifesta algo que eles mesmos não são" (Adorno, 1999, p.114). Uma intelecção fundamental da dialética é de que a coisa não é idêntica consigo mesma, que seu interior é determinado não por ela mesma, mas pela totalidade na qual ela se encontra aprisionada. No texto da controvérsia com Popper, Adorno parece colocar uma ênfase ainda maior no papel hermenêutico da categoria da totalidade, em comparação com o texto da Dialética Negativa. Mas não parece haver diferenças estruturais na concepção do conceito de totalidade nos dois textos. A totalidade segue sendo uma categoria crítica, e não afirmativa:

A crítica dialética se propõe a ajudar a salvar ou restaurar o que não está de acordo com a totalidade, o que se the opõe ou o que, como potencial de uma individuação que ainda não é, está apenas em formação. A interpretação dos fatos conduz à totalidade, sem que esta seja, ela própria, um fato. Não há nada socialmente fático que não tenha seu valor específico nessa totalidade. Ela está preordenada a todos os sujeitos singulares, porque estes obedecem à sua contrainte por si mesmos e até mesmo por sua constituição monadológica, e inclusive, por causa desta, representam a totalidade. Neste sentido, ela constitui a mais efetiva realidade. Na medida em que é a síntese da relação social dos indivíduos entre si, a obscurecer-se em face do singular, ela, contudo, simultaneamente é também aparência, ideologia (idem, p.115).

A dialética pretende determinar a diferença entre particular e universal, sem que esse universal esteja dado como "fato". É muito mais a análise do particular 
que conduz à totalidade. Segundo Adorno, "a totalidade não é fática como o são os fenômenos sociais singulares” (idem, p.116). Mais uma vez, não é uma pura abstração proveniente do "método", quando este se volta para a realidade e estabelece relações triviais de tudo com tudo. Trata-se do "teor básico da sociedade", a troca, que exige a submissão de todos à sua própria lei abstrata, "sob pena de sucumbirem, independentemente de serem ou não subjetivamente conduzidos por um 'afã de lucro'” (idem, ibidem). Vemos no trecho supracitado o esforço de Adorno em pensar a totalidade como real de um lado ("...neste sentido, ela constitui a mais efetiva realidade...”), e como aparência de outro (“...ela, contudo, simultaneamente é também aparência, ideologia").

0 procedimento da dialética pode ser diferenciado daquele do positivismo precisamente pela relação com a totalidade. No caso da dialética, a totalidade é considerada “objetiva”, e seu efeito é determinável em cada constatação social singular. As teorias positivistas, por sua vez, escolhem categorias "as mais gerais possíveis", reúnem-nas "sem contradição em um contínuo lógico, sem reconhecer os conceitos estruturais superiores como condição dos estados de coisas por eles subsumidos", e com isso acabam por "mitologizar a ciência". O positivismo "se fecha à experiência da totalidade cegamente dominante" (idem, p.117), desconhece que só é possível interpretar os dados sociais percebendo a totalidade em seus traços (idem, p.130).

Muito embora Adorno recorra ao conceito de totalidade no texto da "Controvérsia..." para enfrentar as objeções positivistas, ele não deixa de marcar uma diferença fundamental com a dialética hegeliana. Por mais que ele reconheça em outros momentos que a crítica à "instituição científica positivista" já aparece “completamente desenvolvida em Hegel” (Adorno, 2013, p.157), isso não supõe que se deva assumir os conceitos da dialética tais como aparecem em sua versão idealista. Também no texto da "Controvérsia...", Adorno constata o malogro da dialética idealista, que teria, tanto quanto o positivismo, recaído no "mito da razão total" (Adorno, 1999, p.113).

No entanto, mesmo com as críticas a Hegel, ele afirma que a dialética pode se legitimar através da "retradução deste conteúdo na experiência de que proveio" (idem, ibidem). Tal conteúdo não é senão "a experiência da mediação de todo singular por meio da totalidade social objetiva" (idem, ibidem). Na dialética hegeliana, tal experiência estaria disposta "de cabeça para baixo, segundo a tese de que a objetividade precedente, o próprio objeto, entendido como totalidade, é sujeito" (idem, ibidem). Dispor a dialética hegeliana “de cabeça para baixo" quer dizer aqui que essa objetividade entendida como totalidade não é (e nunca foi) um "sujeito global” ou um "sujeito social global”, isto é, um sujeito coletivo.

A relação entre sujeito e objeto é mais assimétrica do que Hegel havia 
pensado: o objeto aparece como mais determinante na formação do sujeito do que o contrário, por mais que a dialética deva reconhecer a relação nas duas direções. O papel de constituição da realidade não está no sujeito, como o idealismo havia pensado, pois "a sociedade" é "tanto um conjunto de sujeitos quanto sua negação" (Adorno, 2009, p.17). A totalidade social permanece irreconciliável com os sujeitos, pois a razão, que opera com a identidade, reduz todos a um denominador comum. Essa universalidade é "verdadeira" porque forma de fato um sistema que conecta tudo e todos, mas é "falsa” porque ainda não é razão alguma (idem, ibidem). Com isso, o sujeito não é mais o todo pelo qual ele se toma: o que faz a mediação dos fatos "não é tanto o mecanismo subjetivo que os forma previamente e os concebe, mas a objetividade heterônoma em relação ao sujeito, a objetividade por detrás daquilo que ele pode experimentar" (idem, p.147). Essa “objetividade heterônoma”, responsável pela mediação dos fatos, é o que não apenas autoriza, mas obriga a dialética a refletir com um conceito de totalidade:

Todavia, é objetivamente e não apenas por meio do sujeito cognoscente que o todo expresso pela teoria é contido nesse particular que é preciso analisar. A mediação dos dois é ela mesma uma mediação de conteúdo, a mediação através da totalidade social. Mas ela também é formal em virtude do caráter abstrato daquilo que regula a própria totalidade, a lei da troca. 0 idealismo que destilou a partir daí seu espírito absoluto oculta ao mesmo tempo o verdadeiro, a saber, o fato de essa mediação se impor sobre os fenômenos como um mecanismo de coação (idem, p.48).

O que há de condenável no idealismo é o fato de que ele se comporta ideologicamente, como se a coação perpetrada pelo todo constituísse um estado reconciliado. No entanto, seu mérito consiste em apresentar esse estado de coisas com um grau de precisão que nenhuma outra filosofia conseguiu alcançar.

Assim, se o conceito de totalidade é imprescindível para uma crítica dialética da sociedade, não quer dizer que Adorno esteja retomando a concepção de sujeitoobjeto idêntico de Hegel ou de Lukács. A totalidade aponta muito mais para uma objetividade que engloba os sujeitos, o "éter" que une todos os momentos e elementos sociais por meio do princípio da troca. Desse modo, ela age de fato na formação dos elementos subsumidos a ela, mas em um sentido negativo. Seu poder e efetividade levam Adorno a afirmar que uma filosofia que deixa de fazer remissão à totalidade acaba por negar seu próprio projeto.

Referindo-se ao procedimento micrológico em outro momento, Adorno chega a afirmar que o modo dialético de compreender a sociedade considera mais a micrologia do que o positivista, precisamente por sua relação com a totalidade: "porque o fenômeno singular encerra em si toda a sociedade, a micrologia e a mediação constituem contrapontos mútuos através da totalidade" (Adorno, 1999, p.135). Na medida em que o princípio da troca faz a mediação de todas as relações, 
os elementos individuais, não-idênticos consigo mesmos, refletem o todo que os precede:

Quanto mais socializado é o mundo, quanto mais espessamente é tecida a camada de determinações universais que envolve seus objetos, tanto mais o estado de coisas singular (...) tende a se tornar imediatamente transparente em vista de seu universal; tanto mais ele pode ser trazido à tona e visualizado justamente por meio de uma imersão micrológica (idem, p.78).

Com isso, a insistência na tese do domínio do todo tem justamente o efeito de marcar que o indivíduo ainda não é o elemento substancial na sociedade: 3 "a contradição entre o universal e o particular tem por conteúdo o fato de que a individualidade ainda não é e por isso é ruim onde ela se estabelece" (Adorno, 2009, p.132). Assim, por mais que a dialética negativa, contra a intenção fundamental da dialética hegeliana, volte seu olhar para o particular, seu intuito é o de marcar aquilo que, no particular, ainda não é ele mesmo, precisamente por sua relação com o todo: "é somente nos traços do indivíduo massacrado e violado que sobrevive a imagem da liberdade contra a sociedade" (idem, ibidem). No entanto, mesmo que apareça sempre marcado pelo universal, o particular nunca é completamente absorvido por ele, pois o não-idêntico resiste a uma identificação total.

Por mais que vise ao particular, em nenhum momento a Dialética Negativa afirma a existência de um "primado do particular", pois tal afirmação seria pura ideologia, apenas encobriria “o quanto o particular se tornou função do universal” (idem, p.260). Precisamente por isso, o conhecimento não dispensa uma relação com universal, pois este, na forma da lei da troca que se realiza no capitalismo "sobre a cabeça dos homens" (idem, p.293), é o que faz com que o indivíduo permaneça, em certa medida, uma utopia. Para que houvesse de fato um "primado verdadeiro do particular", seria preciso uma "transformação do universal" (idem, p.260). Um conhecimento que dispensasse de uma reflexão sobre o universal não poderia mais ser denominado dialético:

A mediação dialética do universal e do particular não autoriza a teoria que opta pelo particular a, de maneira ultrarrápida, tratar o universal como uma bola de sabão. Pois nesse caso a teoria não poderia apreender nem o predomínio pernicioso do universal naquilo que se acha estabelecido, nem a ideia de uma situação que, conduzindo os indivíduos ao que lhes é próprio, privaria o universal de sua má particularidade (idem, p.170).

\footnotetext{
3 Na Dialética Negativa, as considerações de Adorno oscilam entre afirmações mais enfáticas, segundo as quais já não há mais propriamente "indivíduo", até colocações mais moderadas que apontam para o seu declínio, mas não para um desaparecimento completo. $\mathrm{Na}$ verdade, tanto quanto as considerações sobre o domínio da totalidade, em muitos momentos colocado como "absoluto", essas passagens possuem mais uma intenção crítica do que propriamente descritiva. A ênfase na negatividade e a recusa em apostar em "reconciliações parciais" são os elementos que fornecem à dialética negativa sua força crítica.
} 
Uma teoria que ignore a mediação do todo não apenas deixa de apreender "o predomínio pernicioso do universal naquilo que se acha estabelecido", mas também uma situação que seria o contraponto à dominação, situação esta em que os indivíduos seriam conduzidos “ao que lhes é próprio". Em outra passagem, Adorno chega a afirmar explicitamente que investigação de um objeto social torna-se falsa quando "ignora a determinação do objeto pela totalidade" (idem, p.142).

\section{Possibilidades de interpretação}

Ao contrário do que afirma Schnädelbach, tal como mencionamos anteriormente (pp.3-4), Adorno não parece recair em um "holismo" ou em uma "ontologia holística”, nem exigir que a categoria da totalidade possa ser "justificada de maneira idealista" ou, menos ainda, "confirmada de maneira empírica". A totalidade não possui um estatuto ontológico propriamente, não está dada como um "fato" na sociedade. Além disso, Adorno defende que ela funciona como sistema, e não como um organismo. Não se trata de um todo no qual cada órgão possui sua função. A relação de troca é "disposta objetivamente sobre seus elementos" e, com isso, "a mesma conexão que perpetua a vida, simultaneamente a dilacera, e por isto já possui em si aquele algo da morte em cuja direção se move sua dinâmica" (Adorno, 1999, p.134). A totalidade, para relembrar uma passagem central do texto da "Controvérsia...", não é uma categoria afirmativa, mas sim crítica (cf. idem, p.115).

Entretanto, assegurar pura e simplesmente que a totalidade não seja uma categoria ontológica não resolve magicamente todos os problemas. Afinal, como pode Adorno dizer que o conteúdo de verdade do conceito hegeliano de totalidade é sua realização satânica como o sistema de uma sociedade radicalmente socializada, ou que a totalidade hegeliana é o ens realissimum para os indivíduos impotentes diante do todo (Adorno, 2013, p.102) e, ao mesmo tempo, defender obstinadamente o reconhecimento do não-idêntico, uma instância que resistiria à pretensão de onipotência da dominação conceitual e, dessa forma, denunciaria o todo como apenas uma ilusão? Como pensar, por um lado, a totalidade como real, e, por outro, como aparência? A pretensão de dominação identitária torna-se efetiva ou há algum aspecto de resistência que possa desmentir a identificação total?

A solução colocada por Jay consiste em pensar o diagnóstico de Adorno como uma tentativa de combinar dois níveis de explicação: no nível macrológico, uma análise cada vez mais sombria da totalidade e, no nível micrológico, um apelo à resistência no nível teórico e artístico: “ou a totalidade era completamente impenetrável em seu poder reificante (...), ou a totalidade ainda continha negações, e as descrições de Adorno a respeito de sua 'falsidade' satânica eram exageros" (Jay, 1984, p.265). Para Jay, faltaria em Adorno um exame do "nível intermediário" entre esses dois 
extremos, entre o indivíduo isolado capaz apenas de resistir, e a própria totalidade. Toda ênfase no papel do não-idêntico significa que o filósofo frankfurtiano "poderia apoiar-se apenas nos atores mais individualistas para resistir à pressão do todo. Apesar de sua ênfase na mediação, ele fez pouco esforço em investigar as forças e formas sociais concretas entre o indivíduo e a totalidade" (idem, p.271). Com sua excessiva crítica ao conceito de totalidade, esta parece ter se transformado "em um medo de qualquer coisa coletiva, comunitária ou intersubjetiva" (idem, p.274). Não haveria, portanto, qualquer proposta de solução através de um sujeito coletivo, ou mesmo de meios políticos de qualquer tipo. Como a integridade do sujeito individual estaria em perigo de liquidação, toda forma de “meta-subjetividade" deveria ser criticada. Nesse ponto, Adorno seguiria o dito nietzschiano segundo o qual "a insanidade é algo raro no indivíduo - mas em grupos, partidos, povos, épocas, é a regra”. ${ }^{4}$

Jay também acentua o fato de que a categoria da totalidade não é retomada do idealismo tal e qual, pois, para Adorno "a própria noção de um meta-sujeito capaz de totalizar a realidade era uma hipóstase ilegítima tomada da noção idealista de sujeito transcendental", sendo que tal hipóstase remeteria à dominação do valor de troca sobre as relações sociais. O conteúdo de verdade do idealismo diz respeito ao fato de que, devido a essa dominação, os sujeitos de fato refletem a totalidade, mas uma totalidade do tipo mais opressivo (cf. idem, pp.259-260).

Sommer (2016, p.69), por sua vez, referindo-se à explicação de Jay (em Marxism and totality), mais especificamente à alternativa formulada por ele, afirma que a totalidade não é nem "impenetrável”, nem um "exagero". O uso adorniano da totalidade não coloca o filósofo em contradição, pois, na verdade, a própria totalidade é contraditória, ou não-idêntica consigo mesma: ela não corresponde ao seu próprio conceito. A totalidade não é apenas um conceito da dialética, mas também um conceito dialético: ${ }^{5}$ ela não corresponde inteiramente ao seu conceito precisamente porque não pode dissolver o não-idêntico, porque a identificação conceitual "total" não se efetiva por completo. A totalidade, paradoxalmente falando, não é total, ela é apenas "tendencialmente total" (idem, p.70).

$\mathrm{Na}$ verdade, essa intelecção não escapou completamente a Jay. Este reconhece que os conceitos de Adorno não devem ser tomados como fiéis à realidade, e que, quando o filósofo falava sobre a "sociedade totalmente socializada", por exemplo, "ele deveria ser entendido como posicionando um objeto conceitual que não era completamente equivalente à sua contraparte real” (Jay, 1984, p.265), isso porque,

\footnotetext{
4 Adorno (2015b, p.87) cita essa passagem do aforismo 156 de Além do bem e do mal, de Friedrich Nietzsche, no ensaio "Sobre a relação entre sociologia e psicologia" (1955).

5 Como nota Sommer (2016, p.36), não apenas o conceito de totalidade, mas todos os conceitos centrais da dialética negativa, como mediação, negatividade e não-identidade não são apenas conceitos da dialética, mas conceitos dialéticos, isto é, seu sentido implica sempre também seu contrário: particular, imediatidade, positividade e identidade.
} 
mesmo em seus trechos mais sombrios, "há sempre a salvação de que conceito e objeto são necessariamente não-idênticos". ${ }^{6}$ Isso é o que permite que Adorno possa sustentar posições incompatíveis sem se preocupar sobre sua coerência, pois considera que o fetiche pela consistência lógica é ele próprio uma manifestação do princípio de identidade (idem, p.266).

É certo que o elemento de "exagero" é um componente importante do texto de Adorno. Jay recorre a Rose (1978, p.79) para lembrar que o uso adorniano da totalidade é um exemplo do uso "antirrealista" que o filósofo faz dos conceitos, o que fica bem expresso na seguinte passagem de Minima Moralia:

Enquanto o pensamento se refere a fatos e se move na crítica a eles, seu movimento depende da distância mantida. Ele exprime de modo exato o que é, precisamente porque aquilo que é, nunca é inteiramente tal como o pensamento o exprime. Para ele é essencial um elemento de exagero, de ir além da coisa, de liberar-se do peso do factual, para que, em vez de meramente reproduzir o ser, ele possa ao mesmo tempo rigorosamente e livre, determiná-lo (Adorno, 2008, p.123).

Não se trata, portanto, de ler as afirmações acentuadamente sombrias ou apocalípticas de Adorno como meros “exageros" que não devem ser tomados ao pé da letra, ou que devem ser suavizados em nome do bom senso, mas de entendêlas como um aspecto fundamental não só da exposição, da "forma", mas mesmo do conteúdo crítico do pensamento adorniano: "a pretensão de desenvolver todas as mediações fundamentais envolvidas em uma passagem conceitual simplesmente justifica o existente, reproduzindo-o. Saltar mediações tem o efeito de um choque crítico" (Januário; Nobre, 2014, p.46).

No entanto, Sommer tem razão ao enfatizar que a contradição não é meramente uma exigência do "método", mas está no próprio objeto analisado, que é referido como "sociedade antagônica", "totalidade antagônica”, e outras expressões similares. Que Adorno se volte contra uma teoria que busca uma conclusão coerente sobre a sociedade (como a sociologia positivista, por exemplo), isso se deve à própria coisa "não-reconciliada”, que "é plena de contradições e se opõe a toda tentativa de interpretá-la de maneira unívoca” (Adorno, 2009, p.126). Não é, portanto, o “método” que o exime de preocupar-se sobre a coerência da teoria, mas a própria totalidade social, que é contraditória em si mesma: “é concebível que a atual sociedade seja refratária a uma teoria coerente em si (...) A irracionalidade da atual estrutura social

\footnotetext{
6 É válido notar que, por mais que não tematize expressamente a ruptura entre a Dialética do Esclarecimento e as obras tardias de Adorno, Jay (1984, p.261) afirma que, no caso da primeira, o conceito de totalidade teria perdido todas as conotações positivas e se tornado quase sinônimo de totalitarismo. No capítulo "Elementos do antissemitismo", por exemplo, Adorno e Horkheimer afirmam que "entre o antissemitismo e a totalidade havia desde o início a mais íntima conexão" (Adorno; Horkheimer, 1985, p.142), e nesse contexto os judeus aparecem como o "outro" que a razão totalitária deveria absorver e eliminar. No caso da Dialética Negativa, por outro lado, a análise de Jay deixa claro que é possível encontrar elementos de resistência, ainda que restritos ao nível micrológico.
} 
impede o seu desdobramento racional em uma teoria” (Adorno, 1986, p.66).

Outra tentativa de combinar e compreender os elementos contraditórios no diagnóstico adorniano foi feita por Marcos Nobre, que chamou atenção para o uso adorniano do conceito de "ilusão socialmente necessária": a totalidade social seria uma ideologia, mas não no sentido de Marx, isto é, de um "véu" que cobre a realidade, e que uma crítica da ideologia poderia desencobrir. Para Adorno, realidade e ideologia se sobrepõem, ${ }^{7}$ e o estado de identidade torna-se a "aparência socialmente necessária" que a dialética negativa deve denunciar: "a dialética é a teoria da nãoidentidade entre sujeito e objeto no interior da formação social em que a lógica da dominação é exatamente a da 'ilusão necessária' da identidade de sujeito e objeto” (Nobre, 1998, p.174). De fato, o próprio Adorno define em determinado momento a totalidade como "aparência socialmente necessária":

Somente se tudo pudesse ter sido diverso; somente se a totalidade (aparência socialmente necessária enquanto hipóstase do universal extraído dos homens individuais) fosse quebrada em sua exigência de absolutidade, a consciência social crítica conservaria a liberdade de pensar que um dia as coisas poderiam ser diferentes (Adorno, 2009, p.268).

Como nota Nobre (1998, p.162), essa “ilusão necessária”, diferentemente daquela tematizada por Kant na doutrina da dialética transcendental, não é natural, mas "radicalmente histórica”, e, portanto, contingente. A realidade se torna ideologia porque há uma “naturalização da ilusão necessária de identidade” (Nobre, 1998, p.175). Na medida em que a verdade e a aparência do pensamento se confundem (Adorno, 2009, p.13), a crítica da ideologia se transforma na "crítica da própria consciência constitutiva" (idem, p.129). A dialética negativa denuncia o elemento histórico e contingente da identidade.

Assim como Sommer, Nobre (1998, p.174) também enfatiza o fato de que essa identidade nunca se efetiva por completo, ainda que tal dominação seja real. 0 que Adorno entende por "crítica imanente", diferentemente de Hegel, é justamente a tentativa de desmentir essa identidade total: "a imanência é a totalidade dessas posições de identidade cujo princípio é aniquilado na crítica imanente" (Adorno, 2009, p.156). Por mais que o estado de identidade apareça como impenetrável, a dialética negativa, ao apontar para o não-idêntico, deve desfazer essa aparência de impenetrabilidade. Se a realidade tornou-se metafísica, trata-se, contudo, de uma metafísica contingente: "por mais insuperável que seja o feitiço, é apenas feitiço" (Adorno, 1999, p.75).

7 Como fica bem expresso na seguinte passagem: "a ideologia não se sobrepõe ao ser social como uma camada destacável, mas mora no ponto mais íntimo do ser social” (Adorno, 2009, p.294) 


\section{Consideração final}

Podemos extrair algumas conclusões a partir do que foi exposto até aqui. Em relação à questão da contradição entre, de um lado, um sistema com pretensões totalizadoras e, de outro, o não-idêntico como resistência, vemos que a totalidade, se pensada como contraditória em si mesma - como defende Sommer, ou como "ilusão socialmente necessária" - como defende Nobre (apoiando-se nas palavras do próprio Adorno), não realiza por completo suas pretensões totalizantes, seja no conhecimento, seja na própria sociedade. A totalidade, enquanto conjunto dos processos de troca que penetram por todos os poros da sociedade de modo a influenciar na determinação dos elementos individuais, faz com que esses, em virtude dessa própria lógica à qual estão submetidos, mostrem-se como não-idênticos consigo mesmos: "aquilo que é, é mais do que ele é" (Adorno, 2009, p.140). Esse "mais" é propriamente o não-idêntico que a dialética negativa pretende trazer à tona. Na sociedade irreconciliada, o nãoidêntico permanece enquanto promessa não realizada, ou ainda, enquanto "utopia".

Outro ponto que pretendemos ter deixado claro diz respeito à indispensabilidade do conceito de totalidade para o procedimento da dialética negativa de Adorno. Ainda que tal conceito dê ensejo a uma pluralidade de leituras possíveis, parece ser um ponto pacífico a compreensão de que sem a referência ao princípio de identidade como possuidor de pretensões totalizantes (independente do julgamento sobre se essas pretensões de fato se efetivam na sociedade), o próprio diagnóstico em torno da noção de "mundo administrado" parece não fazer sentido. É fato que, como muitos dos autores apontam, a totalidade não possui mais na dialética negativa o mesmo lugar que possuía na dialética hegeliana. O próprio papel da crítica imanente consiste em apontar para a não-identidade entre sujeito e objeto, sem nunca conduzi-los a uma unidade. Como vimos, essa alteração não se deve a um mero erro interpretativo por parte de Adorno em relação à dialética hegeliana. Na verdade, a transformação da dialética de sua versão idealista para a materialista e negativa, levando consigo a transformação de todas as suas categorias fundamentais, é a consequência necessária de uma crítica imanente da dialética hegeliana: para que a dialética não sacrifique a si mesma, seu próprio impulso crítico, ela deve eliminar o passo da "negação da negação", da restituição da identidade.

Por fim, a totalidade não é uma categoria ontológica, mas crítica. Que ela não possa ser confirmada empiricamente não constitui de modo algum uma fraqueza. Afinal, a teoria crítica não se interessa pela mera descrição dos fenômenos sociais, mas por uma análise crítica que mantenha a tensão entre conceito e realidade, de modo a não bloquear a possibilidade do diverso. 


\section{Referências}

Adorno, T. (1986). "Capitalismo Tardio ou Sociedade Industrial?". In: Cohn, Gabriel (org.). Theodor Adorno: Sociologia. São Paulo, SP: Editora Ática.

. (1999). "Introdução à controvérsia sobre o positivismo na sociologia alemã". Tradução de Wolfgang Leo Maar. In: Coleção Os pensadores. São Paulo, SP: Nova Cultural.

- (2008). Minima Moralia: reflexões a partir da vida lesada. Tradução de Gabriel Cohn. Rio de Janeiro, RJ: Beco do Azougue.

- (2009). Dialética Negativa. Tradução de Marco Antônio Casanova. Rio de Janeiro, RJ: Zahar.

- (2013). Três Estudos sobre Hegel. Tradução de Ulisses Razzante Vaccari. São Paulo, SP: Editora Unesp.

. (2015a). Einführung in die Dialektik. Berlin: Suhrkamp.

- (2015b). Ensaios sobre psicologia social e psicanálise. Tradução de Verlaine Freitas. São Paulo, SP: Editora Unesp.

Adorno, T.; Horkheimer, M. (1985). Dialética do Esclarecimento. Tradução de Guido de Almeida. Rio de Janeiro: Jorge Zahar Editor.

Bernstein, J. (2004). "Negative Dialectics as Fate: Adorno and Hegel". In Huhn, T. (org.). The Cambridge Companion to Adorno. Cambridge: Cambridge University Press.

Buck-Morss, S. (1977). The Origin of Negative Dialectics. Theodor W. Adorno, Walter Benjamin and the Frankfurt Institute. New York: The Free Press.

Jaeggi, R. (2005). "No Individual Can Resist”: Minima Moralia as Critique of Forms of Life. Constellations, 12 (1), pp. 65-82. DOI: 10.1111/j.1351-0487.2005.00403.x.

Jameson, F. (1997). Marxismo Tardio: Adorno ou a persistência da dialética. Tradução de Luiz Paulo Rouanet. São Paulo, SP: Boitempo.

Januário, A.; Nobre, M. (2014). Exercício de leitura de "Anotações ao pensar filosófico", de Theodor W. Adorno. Cadernos de filosofia alemã, 19 (2), pp.39-65. Recuperado de: http://www. revistas.usp.br/filosofiaalema/article/view/90815. Acesso em: 10 dez. 2018.

Jay, M. (1984). Marxism and Totality: the adventures of a concept from Lukács to Habermas. Berkeley e Los Angeles: University of California Press.

Nobre, M. (1998). A dialética negativa de Theodor W. Adorno: a ontologia do estado falso. São Paulo, SP: Iluminuras/FAPESP.

Repa, L. (2011). Totalidade e Negatividade: a crítica de Adorno à dialética hegeliana. Caderno CRH, 24 (62), pp. 273-284. Recuperado de: https://portalseer.ufba.br/ index.php/crh/article/view/19207/12470. Acesso em: 10 dez. 2018.

Rose, G. (1978). The Melancholy Science: An Introduction to the Thought of Theodor W. Adorno. Nova York: Columbia University Press. 
Schnädelbach, H. (1983). „Dialektik als Vernunftkritik. Zur Konstruktion des Rationalen bei Adorno“. In: Friedeburg, Ludwig von; Habermas, Jürgen. (org.). Adorno-Konferenz. Frankfurt am Main: Suhrkamp.

Sommer, M. (2016). Das Konzept einer negativen Dialektik. Tübingen: Mohr Siebeck. 